\title{
TRANSFORMATIVE SOCIAL INNOVATION IN RURAL AREAS: INSIGHTS FROM A RURAL DEVELOPMENT INITIATIVE IN THE PORTUGUESE REGION OF BAIXO ALENTEJO
}

\author{
Marina Novikova ${ }^{1}$
}

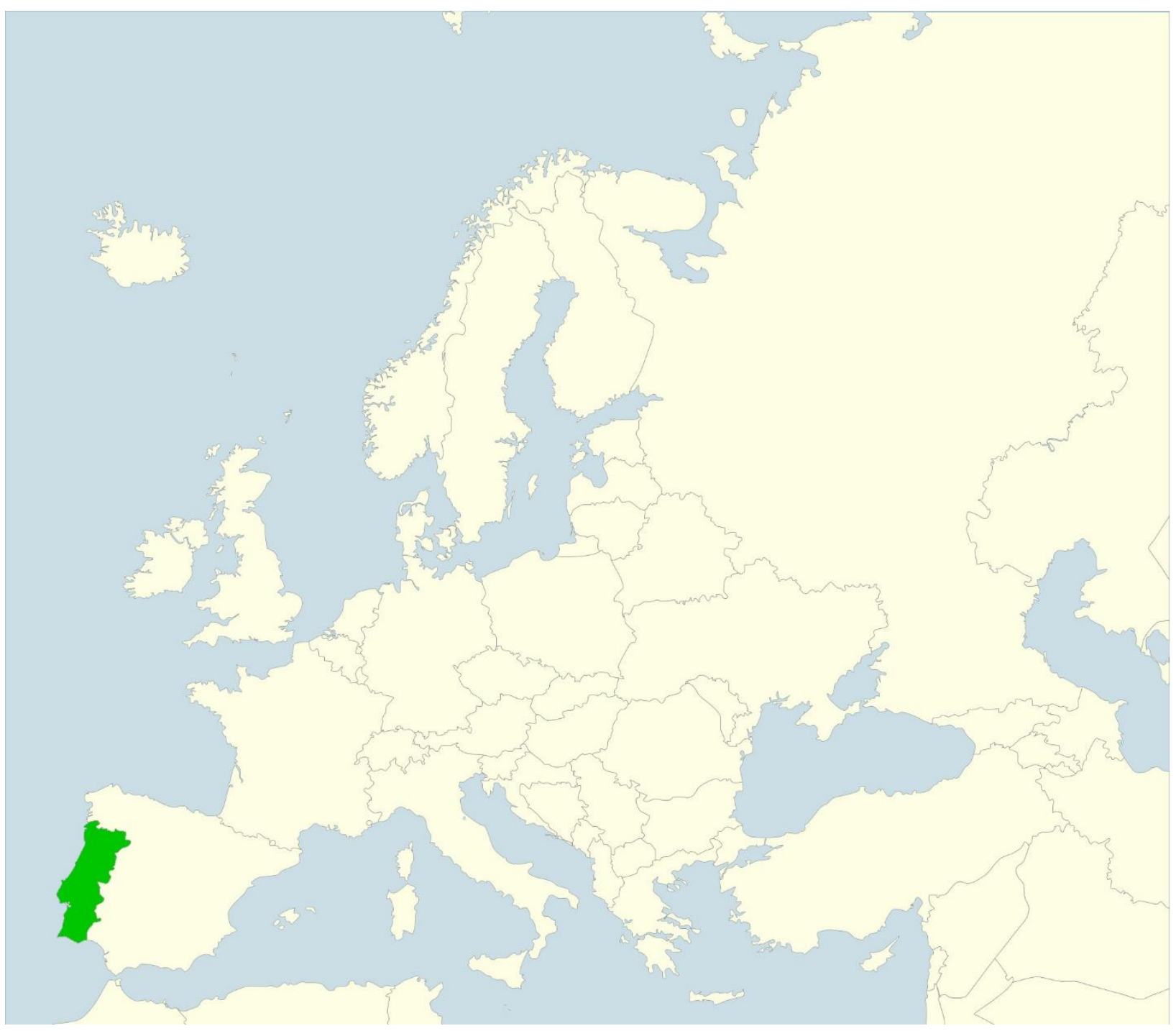

1 Marina Novikova, PhD candidate in Sociology, Integrated Researcher at DINÂMIA'CET-IUL - Centre for Socioeconomic and Territorial Studies, ISCTE - University Institute of Lisbon, Portugal; email: Marina_Novikova@iscteiul.pt; ORCID: 0000-0002-8041-0442. 
Abstract: The role of social innovation initiatives in contributing to sustainable rural development has been discussed both in academia and practice. Some scholars argue that, rather than delivering solely on unmet needs and services, social innovation should have a broader transformative impact. By applying Castro-Arce and Vanclay's analytical framework for transformative social innovation (2020), the paper seeks to analyse the experience of a rural development initiative based in Portugal. The results of this exploratory study indicate that, in triggering bottom-linked governance, the initiative has taken on the bridging roles of knowledge broker, resource broker, shared vision champion, transparency and conflict resolution agent, and network enabler. Alongside taking on these bridging roles, the initiative under study, while promoting cooperation and knowledge exchange, has encountered some challenges further discussed in the paper. Finally, the paper makes some suggestions on how the proposed framework could be enriched.

Keywords: transformative social innovation, rural development, bridging roles, bottom-linked governance, Portugal

\section{Highlights}

- The development of rural regions requires social innovation to have a transformative potential.

- Bridging roles taken on by social innovation initiatives serve as enabling factors for bottomlinked governance.

- Social innovation initiatives must acknowledge critical success factors in triggering bottom-linked governance.

- Rural development actors encounter certain challenges while the promotion of transformative social innovation.

- Regional development can be associated with potential hindering factors for the promotion of transformative social innovation.

\section{Introduction}

The role of social innovation (SI) in the development of urban areas has been widely discussed in the literature and is recognized as a tool for establishing more participatory decision-making and transforming social relations (Moulaert et al., 2009; Mieg \& Töpfer, 2013; Angelidou \& Psaltoglou, 2017; Christmann, 2020). At the same time, despite an initial lag, the research done into the processes underlying the emergence, spread and promotion of $\mathrm{SI}$ in rural regions has begun to catch up (e.g. Neumeier, 2017; Bock, 2016; Katonáné Kovács et al., 2016; Navarro et al., 2018; Sept, 2020), with SI being recognised as 'not only a task for individual and disadvantaged rural areas but a common concern' (Bock, 2016, p. 570).

Within the growing interest in SI for rural development, the relationship between top-down and bottom-up approaches to rural and regional development has been investigated (e.g. see Flora \& Bregendahl, 2012; Maye, 2018), raising questions on how SI processes take place within the top-down/ bottom-up logics. Despite the presence of both research suggesting the need for top-down centralised support for innovation (e.g., Gifford \& McKelvey, 2019) and research advocating for more attention towards the bottom-up character of SI, recent inquiries generally agree on the importance of the combination of approaches (Melnykovych et al., 2018) and the need for establishing a 'meso' level of activity (e.g., Eizaguirre \& Parés, 2019). The research suggests that this 'meso' level can provide a space for actors from various sectors and at different scales to meet and implement policy objectives through programmatic activity' (Courtney \& Powell, 2020, p. 18-19). In the process of establishing and through the functioning of this 'meso' level, 'enablers', 'embedded intermediaries' and 'brokers' play an important role (Neumeier, 2012; Richter, 2019; Castro-Arce \& Vanclay, 2020). They focus on building networks among actors and 
providing space for collaborative action in order to contribute to dialogue between the different levels involved and facilitate projects operating on the ground (Courtney \& Powell, 2020).

The collaborative middle ground where actors share decision-making is understood as bottomlinked governance that 'aspires to become adaptive, enabling more inclusive and effective planning' (Castro-Arce and Vanclay, 2020, p. 53). The aim of such governance, therefore, should not only be in linking bottom-up and top-down logics, but in creating the space for collaboration essential for establishing planning practices designed to address major sustainability challenges. As such, SI initiatives play a crucial role in enabling the bottom-linked governance through building bridges between various sectors and (geographical) contexts, enabling the knowledge and information transfer, acquiring resources, building a shared vision for regional development.

Thus, current research aims at exploring how SI initiatives can contribute to and promote sustainable rural development by triggering bottom-linked governance. By applying the analytical TSI framework by Castro-Arce and Vanclay (2020) and by looking at how SI in rural areas can trigger sustainable change by establishing new practices and/or re-establishing existing practices of cooperation, networking and participation in rural areas, this paper seeks to analyse the case of a rural initiative based in the Baixo Alentejo region of Portugal. As such, the contribution of the paper lies in applying the framework to an initiative operating in a European rural context, providing empirical evidence on how the SI initiative had triggered bottom-linked governance, and addressing some of the potential improvements to the TSI framework applied.

In order to address the proposed research gap, the paper is structured as follows. Section 2 provides the theoretical outlook on the concepts of SI in rural studies and transformative SI as well as presenting the analytical framework applied. In Section 3, the methodology of the paper is explained in more detail. Section 4 presents the case under study with some background information. In Section 5, the analytical framework is applied to the case of a local development association based in rural Portugal, focusing on the bridging roles of the association and the critical success factors for the bottom-linked governance. Section 6 makes some conclusions resulting from the analysis. Finally, Section 7 elaborates on both the potential additions to the framework and makes some suggestions for further research.

\section{2. (Transformative) social innovation for rural regions}

\subsection{Social innovation in rural studies}

Innovation, considered to be a key driver of regional development (e.g., Pike, Rodríguez-Pose \& Tomaney, 2011), has long been approached from the standpoint of technological innovation and economies of agglomeration, placing an emphasis on urban centres. However, such an approach provides a narrow perspective, leaving out other types of territories and other types of innovation (Vercher et al., 2020). As a consequence, the processes underlying SI (e.g., enabling factors, supporting forces, actors arrangements) in rural contexts are still rather understudied.

In an attempt to address this gap, a growing body of research into $\mathrm{SI}$ in rural areas recognises the relevance of SI in developing and sustaining rural communities (Neumeier, 2017; Bock, 2016; Esparcia, 2014; Katonáné Kovács, Varga \& Nemes, 2016; Nijnik et al., 2019; Živojinović et al., 2019). The need for SI in rural communities stems from the fact that quite often rural regions are regarded as marginalised (Lombardi et al., 2020) or structurally weak (e.g., Fischer, 2014) due to the combination of social, economic and environmental challenges they face (Dinis, 2006; Di lacovo et al., 2014; Esparcia, 2014; Dax \& Fischer, 2018). However, such an image of rural areas has been challenged since such regions have the potential to find new ways of addressing such challenges, 'being innovative when they have the necessary space and power to act' (Bosworth et al. 2016, p. 458). Some research argues that rural regions have particular features in terms of innovation and have the potential 'to kick off the discussion on the feasibility of postgrowth trajectories' (Dax \& Strahl 2018, p. 299). By creating more participatory practices (Moulaert et al., 2005), turning towards utilising local resources and recognising their crucial importance for rural development (Neumeier, 2012), as well as by creating new practices that lead to more 
resilience in rural areas (Knickel et al., 2018), SI is thought to represent an important tool in helping regions overcome existing challenges.

The importance of SI initiatives for rural regions stems from their ability to address the gaps that such areas have suffered due to austerity measures and state withdrawal (Bock, 2016; Bosworth et al., 2020). While filling such gaps (e.g., absence of rural services, neglect of cultural and environmental heritage), SI initiatives must strike a delicate balance between the civic selfreliance and self-organisation, and cross-sectoral and translocal collaborations (Bock, 2016, p. 552), where a multi-level middle ground for collaboration is of utmost importance in ensuring decision-making be shared and transparent. This middle ground, being rooted in social collaboration and social learning where novel practices are developed (Bock, 2016), calls for a multi-stakeholder approach where SI processes would transcend both sectoral and geographical division.

Within the literature on $\mathrm{SI}$ in rural areas, $\mathrm{SI}$ is assumed to support rural communities and contribute to their development in several ways. SI can support sustainable rural development through building upon neo-endogenous strategies (Neumeier, 2012) that mobilise local resources to satisfy local public needs and create economic value at the same time (Di lacovo et al., 2014). SI initiatives, by developing actors' context-sensitive arrangements, can support rural communities by contributing to reducing social inequalities and disproportionate resource allocation (Živojinović et al., 2019). Through create and sustaining networks among actors (Neumeier, 2012; Gobattoni et al., 2015) and advancing more efficient collaboration between them (Grinberga-Zalite et al., 2015), SI contributes to rethinking social and spatial solidarity among actors involved (Bock, 2016). By the adaptation of innovative solutions in the form of changed attitudes and practices (Richter, 2019), SI can encourage local linkages and collective learning cultures (Navarro et al., 2018) as well as change unsustainable behaviours and remove structural constraints (Gobattoni et al., 2015). Applied thusly, SI has the potential to contribute to the sustainable development of rural areas through collective action and community selfadvocacy.

\subsection{Analytical framework of transformative social innovation}

SI has been understood to be gaining importance over technological innovation as the latter has become seen as unable to tackle societal challenges in their full complexity (Howaldt \& Kopp, 2012). However, viewing SI as a 'perfect tool' or 'panacea' in meeting major societal challenges underestimates the complexity of these challenges, understood as 'wicked' (e,g, Rayner, 2006; Nicholls et al., 2015) and 'persistent' (Schuitmaker, 2012). As such, systemic change is seen as necessary in tackling such challenges (Rotmans \& Loorbach, 2010; Avelino et al., 2019), consequently requiring $\mathrm{SI}$ to have a transformative potential. Such transformative social innovation (TSI) has entered the discourse (Haxeltine et al., 2016) as SI that 'challenges, alters or replaces dominant institutions ${ }^{2}$ in the social context' (Avelino et al. 2019, p. 198).

Building upon the ideas of TSI, Castro-Arce and Vanclay (2020) designed an analytical framework in order to explore how SI initiatives promote transformation in a social-ecological system (SES) by fostering bottom-linked governance, understood as a collaborative middle ground where actors from diverse geographical arenas, political levels and sectors meet in order to share decisionmaking (Pradel Miquel et al., 2013). The connection between bottom-linked governance and SI is particularly interesting since bottom-linked governance can be seen as 'both an outcome of SI and as a socially-innovative space of action' (Castro-Arce \& Vanclay, 2020, p. 46).

\footnotetext{
${ }^{2}$ Based on Castro-Arce and Vanclay's elaboration of Ostrom (2005), institutions are understood as both formal and informal arrangements used by actors in order to organise and govern their interaction amongst themselves and with the environment, as well as mechanisms applied for creating and changing such arrangements.
} 


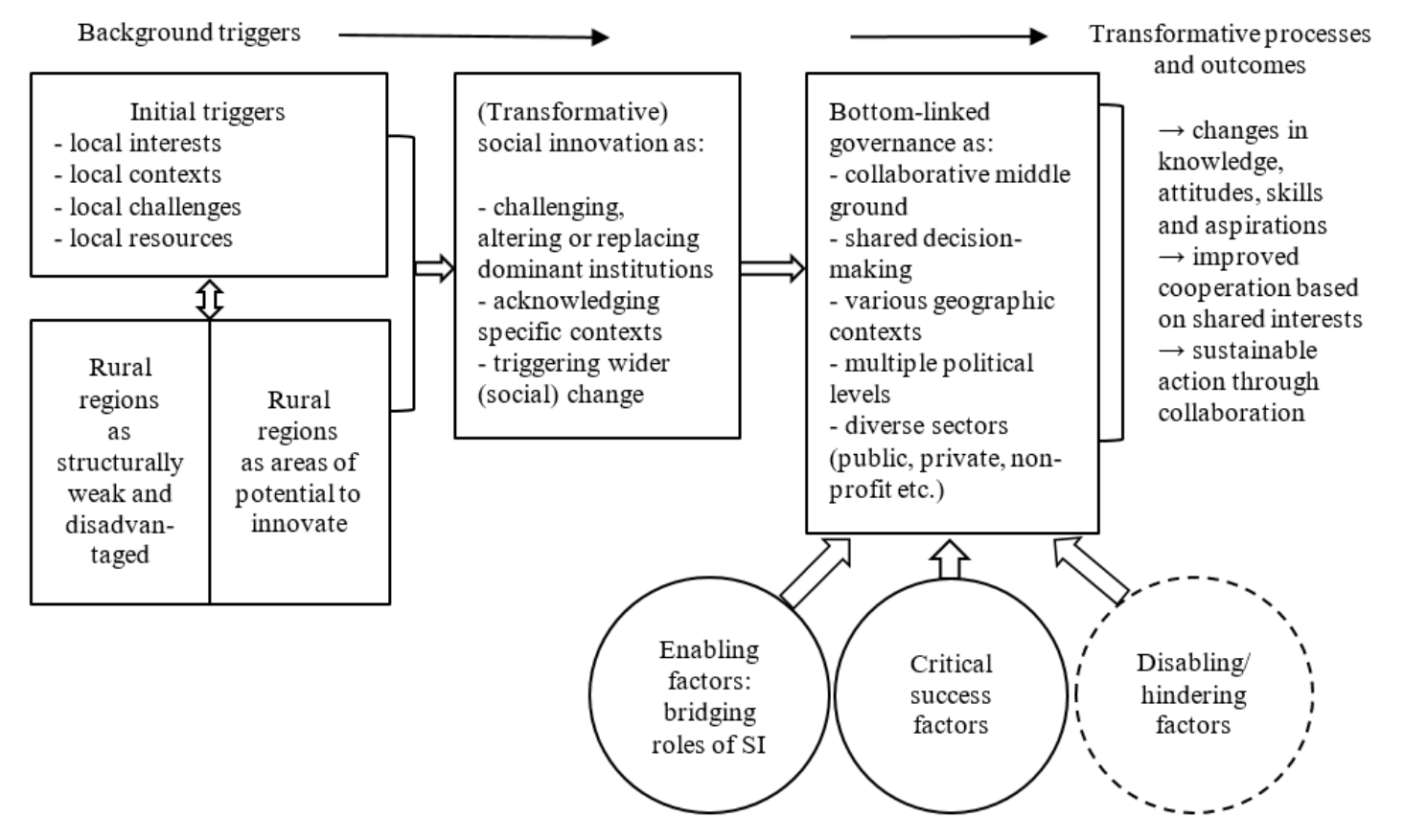

Fig 1. Framework for transformative social innovation. Source: authors, elaborated based on Avelino et al., (2019), Castro-Arce and Vanclay (2020)

SI has evoked many varying approaches and understandings. Notwithstanding, some scholars agree that SI has to have a broader transformative impact (Westley et al., 2016; Novy, 2017; Parés et al., 2017). Such impact, however, cannot be achieved by disconnected local initiatives and actors (Castro-Arce \& Vanclay, 2020). Serving as an intermediary, SI initiatives, therefore, have to take on a role of bridging various sectors of industry, scales and social groups. This capacity to take on bridging roles is central to bridging organisations, understood as those using collaborative mechanisms in order to bring together diverse actors (Crona \& Parker, 2012; Kowalski \& Jenkins, 2015) and bridge local actors and communities with other organisational levels (Olsson et al., 2004). Due to the fact that bridging organisations are of a formal nature, Castro-Arce and Vanclay (2020) suggest applying the term bridging institutions (ibid). Such bridging institutions, due to the varied functions they exercise, have the potential to influence other institutions, governance systems, and the degree of empowerment of local communities through increased participation in and access to decision-making. Additionally, bridging institutions play an important role in crisis management, conflict resolution and the construction of a shared vision among the stakeholders. As such, the five bridging roles, understood as enabling factors of bottom-linked governance, are the roles that must be undertaken by actors involved in SI initiatives for the process of transformation to occur (Table 1). 
Tab 1. Bridging roles of SI initiatives. Source: author's own elaboration, based on Castro-Arce \& Vanclay (2020)

\begin{tabular}{|l|l|}
\hline Bridging roles & Objectives of SI initiatives in triggering bottom-linked governance \\
\hline $\begin{array}{l}\text { Network } \\
\text { enabler }\end{array}$ & $\begin{array}{l}\text { - developing networks and interconnecting existing ones } \\
\text { - better addressing regional challenges through cooperation at vertical and } \\
\text { horizontal levels } \\
\text { - creating awareness of and empathy for the needs of all actors involved }\end{array}$ \\
\hline $\begin{array}{l}\text { Knowledge } \\
\text { broker }\end{array}$ & $\begin{array}{l}\text { - providing a forum for sharing, translation and creation of knowledge } \\
\text { - promoting and connecting local knowledge and expertise to the extra-local know- } \\
\text { how }\end{array}$ \\
\hline $\begin{array}{l}\text { Resource } \\
\text { broker }\end{array}$ & $\begin{array}{l}\text { - serving as arenas for shared decision-making } \\
\text { - bridging the resources (financial, human, social, etc.) leading to win-win outcomes } \\
\text { - contributing to reduction of transaction costs (in monetary, political and social } \\
\text { terms) }\end{array}$ \\
\hline $\begin{array}{l}\text { Transparency conflict } \\
\text { resolution } \\
\text { agent }\end{array}$ & $\begin{array}{l}\text { - facilitating participation and collaboration of actors around common agendas } \\
\text { - serving as an intermediary in resolving the conflicts arising around conflicting } \\
\text { interests } \\
\text { - contributing to establishing the trust among the actors in the networks }\end{array}$ \\
\hline $\begin{array}{l}\text { Shared vision } \\
\text { champion }\end{array}$ & $\begin{array}{l}\text { - enacting a process of creating a shared vision of sustainable regional } \\
\text { development } \\
\text { - aligning visions and missions through collaboration and resources sharing } \\
\text { - acknowledging and addressing different aspirations and needs }\end{array}$ \\
\hline
\end{tabular}

Alongside the bridging roles described in their work, Casto-Arce and Vanclay (2020) place an emphasis on success factors that need to be taken into account when discussing the potential of SI to trigger a transformative change and bottom-linked governance. As such, the first success factor is the acknowledgment of the fact that both the interests of local communities and the social-ecological context will change over time. The process, in which local communities actively advocate for the satisfaction of their needs, may potentially lead to the satisfaction of such needs but also to a change in their (future) needs and concerns. Thus, the authors argue that TSI is an ongoing, 'iterative process that reveals opportunities to change, while inspiring and initiating change' (Casto-Arce \& Vanclay, 2020, p. 49).

The second success factor that needs to be acknowledged is that the local action delivers better sustainability outcomes only when it aims to scale-up at multiple levels, including geographical scales as well as political levels of cooperation. It stems from the fact that, despite innovative initiatives being important at the local level, in order to contribute to sustainability and to be truly transformative, such initiatives have to operate at wider levels. Such local initiatives can have a broader scope of influence, consequently leading to a greater scope of outcomes, when accompanied by resources and support from formal institutions.

The acknowledgement of the necessity for cooperation with formal institutions in order to enable and sustain transformation is the third success factor. Formal institutions, especially when they are characterised by flexibility, open-mindedness, and a willingness to take risks, as well as when such formal organisations trust in community engagement, play a key role in developing policies and regulations to guide enhanced regional development and future SI (Castro-Arce \& Vanclay, 2020). Being supported by such institutions, SI initiatives can gain the resources needed for the innovation process to be continuous.

Lastly, the fourth success factor for the transformative potential of $\mathrm{SI}$ is the acknowledgement of the need for power and decision making to be shared in the governance system. As outlined before, SI has to act on and between different sectors (both public and private), political levels and geographical scales (Castro-Arce \& Vanclay, 2020). Through tasks and resources being distributed among actors as well as through knowledge and decision-making being shared, 
socially innovative initiatives promote cooperation, contribute to conflict resolution and aim at the empowerment of actors.

By taking on these bridging roles and acknowledging the critical success factors presented previously, SI initiatives play an important role in mediating between the top-down and bottom-up forces and actors. As such, the TSI framework serves as an analytical tool to be applied to rural $\mathrm{SI}$ in order to analyse how such SI can trigger the processes of transformation through bottomlinked governance, promoting multi-scale and multi-level cooperation, contributing to empowerment, knowledge transfer, resource acquisition and mediation between stakeholders.

\section{Methods}

In the current paper, an SI initiative from Baixo Alentejo, Association for the Development of the Municipality of Moura (Associação para o Desenvolvimento do Concelho de Moura, in the text - ADC Moura), has been used as a case study, selected as the exemplar based on its rural focus and its active involvement in the community over the last two decades of intervention promoting training, entrepreneurship and business creation, as well as institutional and strategic cooperation.

The research undertaken was a qualitative case study. Data was collected through document analysis (e.g. internal reports) as well as analysis of other related sources (e.g. web-page of ADC Moura,). Such analysis was applied to identify the organisation's aims and objectives as well as to gain a systematic overview of the projects implemented and the stakeholders involved. Narrative data was collected through expert interviews with key stakeholders recruited by the means of snowballing sampling (e.g. Noy, 2008) with key experts identifying and recommending further contacts. This technique was applied since the expertise in the field of SI is not a robust, clearly defined quality (Chatzichristos \& Nagopoulos, 2020). During a secondment with ADC Moura between March and May 2019, 16 interviews were collected. The actors interviewed were ADC Moura's staff, members of the local government and regional agencies dealing with regional and rural development, as well as members of local action groups (LAGs). Additionally, the actors interviewed represented the partners of ADC Moura in implementing and running projects. The interview guide included open-ended questions focusing on: 1) the challenges rural areas face (initial triggers) and the responses aimed at solving those challenges (responses provided); 2) projects and activities initiated; 3 ) the constellations of actors and/or networks that the association is actively collaborating with; 4) enabling and constraining factors in the organisation's work, including those challenges concerning cooperation and collaboration while promoting SI. In order to comply with the ethical concerns of the research (e.g. Vanclay, Baines \& Taylor, 2013), informed consent was obtained for all interviews, elaborating both on the research procedures and the possibility for the interviewees to withdraw at any time. The interviews were conducted in both English and Portuguese, with the latter being translated into English.

Following that, the interviews were transcribed and analysed using the thematic analysis, a method for "identifying, analysing and reporting patterns (themes) within data" (Braun \& Clarke, 2006, p. 79) constituted by several stages (ibid). After the first stage of initial coding, the produced initial codes were used in order to identify emerging patterns and their potential to be allocated to certain themes. As the themes that were identified as a result of coding were covering many domains, current paper focuses mostly on those themes that can be identified as i) SI addressing local needs and/ or providing a response to local challenges, ii) constellations of actors while designing, implementing and running SI projects, iii) the roles that the initiative has taken on while promoting SI, and iv) potential challenges and difficulties faced while working on SI projects for overall rural development.

Based on the analysis of the empirical data collected, following sections discuss the case under study in more detail and draw on some findings discussing the role of ADC Moura, a rural SI initiative, in the process of Baixo Alentejo's development. 


\section{Case study of ADC Moura: a local development association from rural Portugal}

According to the literature, over recent decades, Portugal has been suffering from unemployment and migration of populations towards urban areas (especially with regards to younger generations) due to various factors such as rural land abandonment and land desertification, absence of employment alongside ageing population combined with low population density (Pinto-Correia, Barroso \& Menezes, 2010; Figueiredo \& Pereira, 2011; Campos et al., 2016; Oliveira \& Penha-Lopes, 2020; Pato, 2020).

Baixo Alentejo region, the core intervention area of ADC Moura, is no exception. Being classified as a predominantly rural region (Eurostat, 2016) and identified as a 'moderately weak' rural region (Hennebry \& Stryjakiewicz, 2020), the region is dealing with one of the lowest population densities among Portuguese regions (Eurostat, 2019), coming to 14.1 inhabitants $/ \mathrm{km}^{2}$. The combination of low population density, population decline and high levels of age dependency, might have a strong influence on business development, outmigration and ageing population potentially leading to a deepening of the disparities between regions and furthering the 'littoralisation' process understood as disparities between the coastal and the more in-land regions of Portugal where wealth is concentrated in coastal regions "while the inland regions have remained neglected and underdeveloped' (Hennebry \& Stryjakiewicz, 2020, p. 6).

However, despite some authors suggesting that such a situation 'is a constant' in the Portuguese countryside (e.g., Pato, 2020, p. 213) - and although this has been the trend in recent decades, - 'a new countryside is beginning to shift towards more diverse neo-rural expressions' (Oliveira \& Penha-Lopes, 2020, p. 34). Such a shift occurring in rural areas requires a change in future approaches to regional development that would go beyond targeting economic growth and would focus on 'local participation, social innovation and establishing trust as preconditions to effectively impact well-being dimensions' (Dax \& Fischer, 2018, p. 297).

In order to overcome said challenges, ADC Moura has been a pioneer in the region with regards to such work. Established in 1993 through the initiative of a group of citizens from the municipality of Moura, ADC Moura's work has been inspired by the principles of local development, social and solidarity economy and equal opportunities. As put by a member of the association:

The reason why $A D C$ Moura was founded was because they [initial members] thought this kind of organisation was needed in the territory to help people develop the new initiatives, to help develop territory. In fact, there was no such organisation that had an integrated view on the territory and that is what ADC Moura does. (Member of ADC Moura, March 2019).

According to ADC Moura's Strategic Plan (Plano Estratégico 2020-2021), over the years, ADC Moura has been acting as a promoter, an interlocutor and as a partner in various projects and initiatives related to the different dimensions of development at the local, regional, national, and international level. The projects initiated by and supported through ADC Moura's work are guided by a concern to meet the aspirations and needs of the people and territories in which they operate. As such, ADC Moura seeks to contribute to lessening the effects of structural weaknesses ${ }^{3}$, within the framework of integrated, participatory, solidary and sustainable development. Such contribution is further explored by applying the idea of the bridging roles taken on by the SI initiative.

\section{Findings}

\subsection{Bridging roles of ADC Moura as enabling factors for bottom-linked governance}

In order to enable bottom-linked governance and work towards shared decision-making between top-down and bottom-up actors, as well as across different sectors and different geographical contexts, SI initiatives have to take on several bridging roles. The bridging roles that focus on

\footnotetext{
${ }^{3}$ Structural weakness here is reflected upon by the ADC Moura members and is understood in terms of combination of lack of services, distance from markets, low population density, aging population, and unemployment.
} 
promoting networks, acquiring resources, sharing knowledge, and working towards conflict resolution are further discussed drawing from the analysis of ADC Moura's projects and interventions.

\subsubsection{ADC Moura as a promoter and enabler of multi-level networks}

One of the flagship projects facilitated by ADC Moura is EPAM (Business development in the aromatic and medicinal plant sector in Portugal). Since the beginning of the initiative in 2011, it has aimed at i) fostering the development of a national network related to the production and sale of aromatic and medicinal plants (PAM), ii) supporting entrepreneurship within the sector and developing the capacity of its agents as well as at iii) disseminating knowledge within and beyond the sector. Due to the ADC Moura's in focusing on needs of the PAM sector in Portugal, EPAM has grown over time to become a nation-wide collaboration (and an 'umbrella' platform for many other projects such as Cooperation to grow the aromatic and medicinal plants sector, COOP4PAM) bringing together PAM producers and farmers, distributors, various development associations and entrepreneurs as well as research entities. One of the main elements of the network was the digital platform and the forum created by ADC Moura as a cooperation and dissemination tool for actors involved in the PAM sector. The creation of this digital platform triggering the process of documenting innovation and 'best practice' was followed by the creation of a database of producers and other agents in the sector. Creation of the database led to the emergence of strong support infrastructure and knowledge exchange through the digital platform ('relative' technological/ digital innovation). As a result, it helped establish the network involving the PAM producers from disconnected rural areas where they can exchange their ideas, propose collaboration projects, seek advice in both horizontal (producer to producer) and vertical (producers to research entities, regional development agencies etc.) manner. Through collaborating towards their common interest - developing the PAM sector in Portugal and beyond - all the actors involved, at the same time, acknowledge different interests of the parties involved.

\subsubsection{ADC Moura as an agent in the transfer of knowledge}

Regarding the transfer of knowledge, ADC Moura established the Centro de Competencias das Plantas Aromaticas, Medicinais e Condimentares (Competence Center for Aromatic, Medicinal and Spice Plants, CCPAM) within the EPAM network. First established in 2015 as a response to the call by the Ministry of Agriculture, Forestry and Rural Development (MAFDR), CCPAM brought together producers, industry, associations, national scientific and research entities and municipalities. Such knowledge transfer between actors acknowledges i) the constraints and needs of economic agents along the chain; ii) importance of applied research and experimentation along the value chain, iii) transfer of knowledge and technologies to companies in the sector; iv) marketing, strengthening skills and seeking innovative solutions that reinforce the sector's competitiveness throughout its value chain; v) promotion of the Portuguese PAM sector's competitiveness, and vi) dissemination of knowledge on potential international partnerships that can leverage the national development of the sector. With the growth of and rising interest in the PAM sector in Portugal, ADC Moura recognised the necessity to create conditions for the development of integrated, collective and strategic action within the sector. Due to the relative novelty of the PAM sector, the space for strategic action based on the knowledge exchange and sharing the expertise was missing. Recognising this, CCPAM serves as a platform for improving the production and dissemination of knowledge by interconnecting research to practice and vice versa. As an outcome, through CCPAM, ADC Moura encourages both sharing of information and knowledge between the bottom-up and top-down levels (vertically) and across sectors, e.g. from research entities to producers (horizontally).

\subsubsection{ADC Moura as a shared vision champion}

Over its 27 years, ADC Moura has been bridging the visions and aspirations of various stakeholders regarding the future development of the region, by bringing together actors from different arenas with their own (not always aligned) interests towards a shared vision of the region's development. Such a shared vision for the future of the region was talked about by interviewees with aspirations built around the ideas of sustainability, interconnectedness, and 
opportunity-driven development. The common aspiration, repeated by both ADC Moura's members as well as partner organisations and institutions, is a sustainable, integrated development of the region that is based on utilising local resources that are unique to the territory:

So one of our main assets is that we have a territory which has a lot of potential and has not been spoiled yet. So one of our goals would be to keep what is unique about our territory and to keep it sustainable, both environmentally and economically (Member of Intermunicipal community of Baixo Alentejo, April 2019).

The shared vision around the potential future development of the wider Alentejo region, based on the interview data, is centered around four main domains that both local development organisations and formal organisations regard as important. The first domain is cooperation, where, instead of being competitive, local and regional actors combine efforts in being more efficient and solidary in their work towards regional development. The second domain that such a shared vision is sustainability, where the actors, instead of pursuing short-term goals and deliverables in projects, attempt to build a support infrastructure for future interventions. The emphasis on connecting local resources and knowledge to wider contexts is the third priority by which such a shared vision is constituted. The fourth domain is concerned with promoting opportunity-driven development instead of just focusing on solving the problems. As such, by promoting a shared vision, ADC Moura aims at changing both the perspective of formal institutions and the local communities on utilising local knowledge and resources towards achieving sustainable rural development.

\subsubsection{ADC Moura as a transparency agent, mediator and conflict resolution agent}

Through its intervention, ADC Moura has been bringing different interests together and acting upon it as a mediator between local communities and public administration. Such mediation can be seen in terms of mediation in capacity building, mediation in budgetary domain and mediation in conflict/ crisis resolution. Within the capacity building domain, the main objectives of ADC Moura's work, in cooperation with the Institute for Employment and Vocational Training (Instituto do Emprego e Formação Profissional), are focused on providing support at all stages of project design, implementation and consolidation by unemployed members of the community. Such work involves support in the preparation of the business plan, monitoring and post-creation consultancy in the first 2 years of activity. As such, it is targeting the creation of independent entrepreneurial activities by the local population, supporting them in acquiring the necessary levels of confidence and knowledge in order to run their own activities in the future without fully relying on ADC Moura's mentoring. As an intermediary in budgetary terms, in a partnership with the municipality of Moura, ADC Moura has been a part of a project promoting participatory budgeting in the municipality of Moura (Orçamento Participativo). Within this initiative, the main aim is to involve the citizens of the municipality in the definition of local public policies, namely in decision making on the investment priorities of the municipal budget, based on a process of reflection and debate about the territory's problems and opportunities. As a result, the local community has a chance to gain direct access to decision making as well as the opportunity to exercise their agency in deciding how the municipal budget would be allocated. Within the domain of mediation in conflict resolution, ADC Moura has been working closely with the Roma community in the wider context of the Baixo Alentejo region. Within the project on municipal mediation (Mediadores Municipais e Interculturais), the aim lies in strengthening the integration of the most vulnerable communities, namely Roma and migrant communities, as well as in deepening intercultural dialogue between the various communities and the host society, promoting social cohesion and improving the quality of life. Facilitated by ADC Moura, such dialogue and partnerships are capable of creating bridges between citizens and institutions, as well as achieving change based on mediation between local actors, bringing actors around the same agenda, preventing conflict or, when necessary, acting on it in a mediating manner.

\subsubsection{ADC Moura's role in acquiring the necessary resources}

ADC Moura's involvement in and facilitation of many projects has allowed the initiative to be more effective and efficient in obtaining resources through established networks covering a wide range 
of public and private partners as well as geographical contexts. By participating in a substantial number of projects facilitated by the European Union (EU), ADC Moura has received organisational and financial support in the domain of research on social entrepreneurship and social innovation (RurAction, Horizon 2020) and active citizen engagement (My Smart Quartier, Erasmus+), with such opening up access to state-of-the-art academic knowledge and best practice on issues related to the ways in which SI initiatives might contribute to sustainable rural development. By being a part of such EU projects, acquiring the academic knowledge and linking such knowledge back to practice - the domain that organisations often lack the time and resources to work on themselves in such depth - ADC Moura has been able to bridge those resources back to the territory. Linking local interests and needs to European, national and regional development frameworks, ADC Moura has been able to acquire resources that, while coming from the EU and national funding, still acknowledge local needs and interests.

Through developing the projects in conjunction with other projects and partners, ADC Moura has been able to maximise the opportunities for project activities and to minimise the related costs. However, the initiative still faces some difficulties in working in the 'patchwork' manner:

[Starting the projects], we try to get some financing, [...] and we always know that we must do this through a puzzle of different projects that when they can come together, we can more or less do most of the strategy. What is happening now is that even the puzzle is becoming smaller and smaller with pieces that no longer can be connected. It is becoming more and more difficult to just put things running (Member of ADC Moura, March 2019).

ADC Moura has been able to overcome financial and operational constraints through partnering with peer organizations (such as Local Action Groups of ESDIME and Terras Dentro) and wider inter-municipal and inter-regional networks (Intermunicipal Community of Baixo Alentejo (CIMBAL) and Portuguese Federation of Local Development Associations (Minha Terra)). Such collaboration manifests as peer exchange, regular meetings, seminars and workshops for the purposes of exchanging and disseminating the latest know-how. Such an approach facilitated the acquisition of support in those domains where local knowledge and resources were lacking. By bringing the missing resources to the territory through networks and by operating through the project work rooted in cooperation and support for more efficient interventions, ADC Moura has taken on a role of resource broker.

In order to create a 'meso' level for actors to come together in the process of rural development, SI initiatives must take on the roles of bridging institutions that have the ability to: promote networks and enable the circulation of knowledge and resources within those networks, while promoting transparency within and beyond their own operations.

\subsection{Critical success factors for transformative regional development: a balancing act}

Alongside bridging roles that are discussed in the TSI framework and that ADC Moura takes on, the critical success factors have to be taken into account. Acknowledging those factors is needed to ensure that, through triggering bottom-linked governance, transformative regional development is to appear.

The first success factor is the acknowledgment of the fact that both the interests of local communities and the social-ecological context will change over time. The process, in which local communities actively advocate for the satisfaction of their needs, may potentially lead to the satisfaction of such needs but also to a change in their (future) needs and concerns. The initial impetus for the work of ADC Moura was a wish expressed by a group of local people to promote an integrated area approach to local development, combining many distinct local community interests and needs. However, over time, ADC Moura has adapted the scope of its interventions based on the changing needs of the community towards more extra-local work, international cooperation, and knowledge exchange between various entities. Within the EPAM project discussed in the previous section (Section 5.1.1), the initial interest was related to the promotion and support of the PAM sector. Going back to 2002, the first professional PAM production and transformation course conducted by ADC Moura was followed by initiatives to enhance floristic heritage through community projects developed in schools within the municipality of Moura. However, strategic work in favor of the Portuguese PAM sector's sustainable development started 
later on in 2009. The project, by meeting the initial needs of local actors in promoting the local PAM sector, reflected the need of local communities towards collaborating with extra-local actors in terms of knowledge exchange, access to the markets etc. This adaptation to changing interests and contexts demonstrates ADC Moura's acknowledgement that the changes are, indeed, occurring, which is further reflected in their integrated, rather than sectoral, approach to development. Despite the EPAM project, initiated by the Rural Development Network of Portugal, falling under a more top-down perspective, the project was actively supported by local actors, and only due to the high interest and the project meeting the needs and aspirations of wider communities, was it scaled-up and multiplied across Portugal rather than staying local.

Secondly, the local action delivers better sustainability outcomes only when it aims at scaling-up at multiple levels, including geographical scales as well as political levels of cooperation. ADC Moura, while prioritising work for and with the local community, realised that, through the process of scaling up its projects, it could have a wider scope of action in addition to wider reach. Returning to the example of the EPAM project, which started as a local initiative, the project has been scaled up to many Portuguese regions asa part of multiple networks, including producers, distributors and researchers joined into national networks as well as other networks and communities at the international level, such as the Mediterranean network CEDDEM - Center d'Etude et de Développement Durable Euroméditerranéen and the European association EUROPAM - European Herbs Growers Association. When it comes to transcending the political levels in delivering better sustainability outcomes, ADC Moura has been actively involved in common projects in collaboration with CIMBAL and Minha Terra as well as the Portuguese Association for Local Development (ANIMAR) which all function on different political levels. Being a part of such intermunicipal and national networks provides a stronger platform for projects to be disseminated within and beyond the local. Doing so allows projects to me implemented across spatial scales and makes their outcomes more stable.

In order to trigger transformative change through the process of bottom-linked governance, the organisations have to acknowledge the necessity for cooperation with formal institutions in order to enable and sustain transformation. As said before, such cooperation is especially fruitful if the formal institutions involved are flexible, open-minded, willing to take risks and ready for the implementation of new solutions to regional development. In the case of ADC Moura, within the frameworks implemented by regional (e.g Regional Development and Coordination Commission of Alentejo) and national formal institutions (e.g. Directorate-General for Agriculture and Rural Development), such collaborations have been key for implementing and running the initiative's projects. However, while cooperation with formal institutions at the regional and national levels has been fruitful and productive, cooperation at the local level (e.g. municipal level) has been described by interviewees as 'difficult'. Despite the association's role as an intermediary between local authorities and the community, the work of ADC Moura is sometimes approached with a certain degree of scepticism from local authorities, which may be explained by the organisation's conscious choice to remain (politically) neutral and autonomous, putting certain constraints on such cooperation. As one interviewee put it:

We at $A D C$ Moura try to be a very civic organisation, independent organisation, and this has a high cost [...] This is a relevant issue in our constraints (Member of ADC Moura, March 2019).

Additionally, in the relations between the municipality and the association, it has been said to be a degree of competition rather than cooperation. Since the resources available in the region are quite scarce, the municipality takes the lead on implementing certain projects in the field of social and community interventions. As a result, as argued in interviews, ADC Moura is only partially involved in those projects run by the municipality. Nevertheless, due to ADC Moura's integrated approach to local and regional development, the municipality's work is seen as rather compartmentalised and sector-oriented, which might also contribute to the existing challenges faced by the association:

Because we are all societal problems are wicked, are very complex [...] you have to integrate many different sectors, many different stakeholders. And we are more prepared 
for those kinds of interventions than municipalities because all the departments are so separated (Member of ADC Moura, March 2019).

As a way of overcoming and mitigating such a barrier at the local level, ADC Moura is actively involved in a myriad of projects at both the national and international level, where the association is said to receive a higher recognition for its work. Having analysed the projects ADC Moura is implementing and participating in, a substantial portion of such projects are of national and international scale. Thus, due to some difficulties with acquiring support at the local level, while keeping the focus on its main area of intervention on Baixo Alentejo, the association counterbalances the constraints experienced at the local level by being actively involved at the extra-local levels of cooperation and networking.

Lastly, the fourth success factor for bottom-linked governance is the acknowledgement of the need for power and decision-making in the governance system to be shared. As argued in the analytical framework by Castro-Arce and Vanclay (2020), in such governance systems, the actors come together to collaborate for the benefit of all - and such collaborations depend on the distribution of power and decision making. However, despite the strong focus on promoting cooperation that cuts across scales (local, regional, national, EU level), and sectors (private, public, third sector) as well as institutions (academic, practice, peers), organisations like ADC Moura have been facing challenges related to some degree of competition among organisations at the regional level. As put by one interviewee representing the formal institution at the regional level:

We are trying to make them [organisations] speak to each other. On paper, they are saying that there will be a regional system of transfer and knowledge, but it was on paper only. It is nice to have it on paper and give it to someone to read it and say oh it is very good, they are doing interesting things...But I think that instead of being competitive, they should be cooperative (Member of Regional Development and Coordination Commission of Alentejo, April 2019)

Despite such constraints, the necessity for both cooperation with formal institutions as well as the need for shared power and decision-making have been acknowledged by ADC Moura, constituting an important part of its work. As such, ADC Moura's work is specifically interested in overcoming such barriers and changing the approach of regional actors from competition to cooperation, thus, creating a shared vision of a region that is achieving its sustainable development through knowledge sharing and resources distribution rather than competing for (already) scarce resources.

\section{Conclusions}

By applying the analytical framework for TSI by Castro-Arce and Vanclay (2020), the paper analysed the case of ADC Moura, a local development association based in rural Portugal. In order to trigger and contribute to sustainable transformation in rural regions, rural initiatives must seek to create wider networks, more just and participatory decision-making through changing the constellations of actors, and the wider transfer and exchange of knowledge within those networks. The results indicate that ADC Moura has taken on the five bridging roles in the development of middle ground collaborative space for regional development. By combining various axes of intervention, as well as by being actively involved in projects not limited to specific sectors (such as agriculture) and scales (despite starting as a local initiative), ADC Moura has demonstrated the ability to transcend the existing structures and become the 'meso-level' organisation. As such, its active engagement in establishing and enabling networks, knowledge exchange, resource acquisition, allowed ADC Moura to create that common space for public and private actors to come together and collaborate, thus contributing towards the triggering of bottom-linked governance.

In the process of bringing about bottom-linked governance, several critical success factors have been identified within the framework proposed by Castro-Arce and Vanclay (2020). Under such, the initiative must acknowledge i) the change in (local) interests and context, ii) the need for the local action to be scaled-up for better sustainability outcomes, iii) the need for cooperation 
with formal institutions to enable and sustain transformation, and iv) the need for the decisionmaking and power within the governance system to be shared. Despite being successful in taking on the bridging roles and acknowledging the critical success factors in the process of bottomlinked governance development, ADC Moura has faced some challenges while trying to establish cooperation at the local level. Results indicate that the initiative faced some degree of competition rather than cooperation at the local level. This may be explained by the conscious choice of the organisation to stay politically independent and the limited pool of resources available at the municipal/ local level. In order to overcome these constraints, ADC Moura has taken on an active role at the regional and national levels due to their wider availability of resources, as discussed in the results.

In keeping with the main idea of transformative SI that it is an attempt to contribute to sustainable development, several conclusions can be drawn. ADC Moura has contributed to the sustainable development of the Baixo Alentejo region in the following ways. First, by establishing multi-level networks (both geographically and politically), the SI initiative has been recognised as a channel between the local communities and other actors. By being actively involved in said networks, ADC Moura delivers upon connecting the local resources with extra-local ones, thus, opening up new channels for knowledge transfer and exchange. Second, ADC Moura's participation and membership in various types of collaborative efforts (intermunicipal community, federation of local development associations) stabilises the outcomes of the projects since, instead of aiming at just scaling-up, they are being implemented and supported throughout wider networks. Third, despite some constraints at the local level, the promotion of collaboration based on a shared vision forms one of the pillars of the organisation's interventions, with an aim to a more cohesive approach to regional development in the future. As expressed by interviewees, even if the change is not apparent, it is a process of constructing and promoting the culture of collaboration based on the shared values and aspirations that ADC Moura is aiming for.

\section{Discussion}

By applying the proposed TSI framework, this paper investigated the case of a local development association based in rural Baixo Alentejo. The case of ADC Moura showed that rural SI can become transformative by engaging various actors and by developing a bottom-linked governance. To this end, the framework serves as a relevant tool for analysing the experience of rural initiatives with great potential for further application, both in research and practice. At the same time, the framework could be enriched by expanding the idea of bridging roles through discovering additional categories. Additionally, alongside enabling and critical success factors for bottom-linked governance, further research could also critically engage with the potential disabling factors for bottom-linked governance.

As outlined above, some more elaboration could be undertaken in expanding upon those other possible bridging roles that rural initiatives take upon themselves. Stemming from the results, two other categories could be added as distinct bridging roles, namely the role of SI initiatives in capacity building and their role in promoting opportunity-driven development rather than that solely focused on satisfying pressing needs.

Concerning capacity building, the results indicate that, despite being partly covered in all interventions by ADC Moura, it is a distinct category of action targeting both the beneficiaries and the peer organisations. In the interviews, the importance of the capacity building was highlighted repeatedly where ADC Moura - and the actors from wider context and networks - see it as one of the most crucial domains and focuses of SI and local development work (Novikova et al., 2020). Having contributed to capacity building, especially of local communities, ADC Moura' s aim has been to establish the independence of locals in implementing and running their own projects and initiatives. Potential for further research also lies in the transition of the local communities' members away from being solely beneficiaries to becoming the actors that contribute towards the development of the region through running their own initiatives, thus, becoming more actively involved in participating in regional development.

Concerning opportunity-driven development, it has been argued that in rural development there has been a shift towards perceiving available local assets as an opportunity and a valuable feature 
rather than an obstacle (Dax \& Fischer 2018). The importance of such opportunity-driven SI compared to that solely based on problem solving stems from the fact that opportunity-driven SI can potentially provide more transformative outcomes (Bosworth et al. 2016), irrespective of problem-oriented actions providing the best available solution at a given time. The results of the current research indicate that opportunity-driven SI helps in re-evaluating available local assets by both rural development actors and the local communities, changing attitudes in favour of seeing a region as a place with enormous potential, and providing a perspective on how unique regional assets can be utilised. As such, the role of SI initiatives in developing solutions that focus on opportunities should be further explored.

While the framework acknowledges critical success factors for bottom-linked governance, more elaboration of the proposed TSI framework could be done into the potential disabling/ hindering factors for bottom-linked governance. Research suggests that in different configurations of actors who might have competing ideas, conflict and tension can emerge (Christmann, 2020). Briefly discussed in the paper, the results indicate that the process of rural development is still associated with some degree of competition both among the SI initiatives themselves and between top-down and bottom-up stakeholders due to the scarsibility of resources and conflicting interests. As such, the conflictual nature of $\mathrm{SI}$ might affect its potential to trigger transformation and should be considered as one of the factors contributing to the success or failure of SI and bottom-linked governance. At the same time, such conflict and contestation, if they are constructively processed, might potentially lead to a positive change rather than a failure of an SI initiative and the change it aims at bringing on (ibid.). Thus, it is important to acknowledge the role of conflicts in SI as a factor for TSI and its ability to trigger bottom-linked governance.

A further point of acknowledgement is that innovation, generally being understood as something desirable or inherently good (Godin, 2012; Coad et al., 2020), calls for more reflection on the potential 'dark sides' of it. Previous research (e.g. Fougère \& Meriläinen, 2019) has identified several 'dark sides' to SI specifically, of which unintended adverse consequences and the negative impacts of SI are of great interest. The applied TSI framework suggests that SI, by triggering bottom-linked governance, aims at transformative change. However, the further development to the framework, could take into account the (unintended) negative consequences of $\mathrm{SI}$ and how both the initiatives and their role in bottom-linked governance can contribute towards avoiding and/or dealing with such consequences.

\section{Acknowledgements}

This research has been carried out in the framework of the RurAction project that has received funding from the European Union's Horizon 2020 research and innovation programme under the Marie Sklodowska-Curie grant agreement No. 721999. The author would like to thank two anonymous reviewers for their helpful feedback and comments on this article. The author would like to express gratitude to the members of ADC Moura for their ongoing support while developing the research.

Academic references

[1] Angelidou, M. \& Psaltoglou, A. (2017). An empirical investigation of social innovation initiatives for sustainable urban development. Sustainable Cities and Society, 33, 113-125. DOI: 10.1016/j.scs.2017.05.016.

[2] Avelino, F., Wittmayer, J. M., Pel, B., Weaver, P., Dumitru, A., Haxeltine, A., Kemp, R., Jørgensen, M. S., Bauler, T., Ruijsink, S. \& O'Riordan, T. (2019). Transformative social innovation and (dis)empowerment. Technological Forecasting and Social Change, 145, 195206. DOI: 10.1016/j.techfore.2017.05.002.

[3] Bock, B. B. (2012). Social innovation and sustainability; how to disentangle the buzzword and its application in the field of agriculture and rural development. Studies in Agricultural Economics, 114(2), 57-63. DOI: 10.7896/j.1209. 
[4] Bock, B. B. (2016). Rural marginalisation and the role of social innovation; a turn towards nexogenous development and rural reconnection. Sociologia Ruralis, 56(4), 552-573. DOI: 10.1111/soru.12119.

[5] Bosworth, G., Price, L., Hakulinen, V. \& Marango, S. (2020). Rural Social Innovation and Neo-endogenous Rural Development. In Cejudo, E. \& Navarro, F., eds. Neoendogenous Development in European Rural Areas (pp. 21-32). Cham: Springer.

[6] Bosworth, G., Rizzo, F., Marquardt, D., Strijker, D., Haartsen, T. \& Aagaard Thuesen, A. (2016). Identifying social innovations in European local rural development initiatives. Innovation: The European Journal of Social Science Research, 29(4), 442-461. DOI: $10.1080 / 13511610.2016 .1176555$.

[7] Campos, I., Vizinho, A., Truninger, M. \& Penha Lopes, G. (2016). Converging for deterring land abandonment: a systematization of experiences of a rural grassroots innovation. Community Development Journal 51(4), 552-570. DOI: 10.1093/cdj/bsv051.

[8] Castro-Arce, K. \& Vanclay, F. (2020). Transformative social innovation for sustainable rural development: An analytical framework to assist community-based initiatives. Journal of Rural Studies, 74, 45-54. DOI: 10.1016/j.jrurstud.2019.11.010.

[9] Chatzichristos, G. \& Nagopoulos, N. (2020). Regional Institutional Arenas for Social Innovation: A Mixed Methods Research. Journal of Social Entrepreneurship, 1-23. DOI: $10.1080 / 19420676.2019 .1705378$.

[10] Christmann, G. B. (2020). Introduction: struggling with innovations. Social innovations and conflicts in urban development and planning. European Planning Studies, 28(3), 423-433. DOI: 10.1080/09654313.2019.1639396.

[11] Coad, A., Nightingale, P., Stilgoe, J. \& Vezzani, A. (2020). The dark side of innovation. Industry and Innovation, 28(1), 102-112. DOI: 10.1080/13662716.2020.1818555.

[12] Courtney, P. \& Powell, J. (2020). Evaluating Innovation in European Rural Development Programmes: Application of the Social Return on Investment (SROI) Method. Sustainability, 12(7), 2657. DOI: 10.3390/su12072657.

[13] Crona, B. I. \& Parker, J. N. (2012). Learning in support of governance: theories, methods, and a framework to assess how bridging organizations contribute to adaptive resource governance. Ecology and Society, 17(1), 32. DOI: 10.5751/ES-04534-170132.

[14] Dax, T., Strahl, W., Kirwan, J. \& Maye, D. (2016). The Leader programme 2007-2013: Enabling or disabling social innovation and neo-endogenous development? Insights from Austria and Ireland. European Urban and Regional Studies, 23(1), 56-68. DOI: $10.1177 / 0969776413490425$.

[15] Dax, T. \& Fischer, M. (2018). An alternative policy approach to rural development in regions facing population decline. European Planning Studies, 26(2), 297-315. DOI: 10.1080/09654313.2017.1361596.

[16] Di lacovo, F., Moruzzo, R., Rossignoli, C. \& Scarpellini, P. (2014). Transition management and social innovation in rural areas: lessons from social farming. The Journal of Agricultural Education and Extension, 20(3), 327-347. DOI: 10.1080/1389224X.2014.887761.

[17] Dinis, A. (2006). Marketing and innovation: Useful tools for competitiveness in rural and peripheral areas. European Planning Studies, 14(1), 9-22. DOI: 10.1080/09654310500339083.

[18] Eizaguirre, S. \& Parés, M. (2019). Communities making social change from below. Social innovation and democratic leadership in two disenfranchised neighbourhoods in Barcelona. Urban Research \& Practice, 12(2), 173-191. DOI: 10.1080/17535069.2018.1426782.

[19] Esparcia, J. (2014). Innovation and networks in rural areas. An analysis from European innovative projects. Journal of Rural Studies, 34, 1-14. DOI: 10.1016/j.jrurstud.2013.12.004. 
[20] Figueiredo, J. \& Pereira, H. M. (2011). Regime shifts in a socio-ecological model of farmland abandonment. Landscape Ecology, 26(5), 737-749. DOI: 10.1007/s10980-011-9605-3.

[21] Fischer, T. (2014). Aging population in change - a crucial challenge for structurally weak rural areas in Austria. European Countryside, 6(1), 9-17. DOI: 10.2478/euco-2014-0002.

[22] Flora, C. B. \& Bregendahl, C. (2012). Collaborative community-supported agriculture: balancing community capitals for producers and consumers. International Journal of Sociology of Agriculture \& Food, 19(3), 329-346.

[23] Fougère, M. \& Meriläinen, E. (2019). Exposing three dark sides of social innovation through critical perspectives on resilience. Industry and Innovation, 1-18. DOI: 10.1080/13662716.2019.1709420.

[24] Gifford, E. \& McKelvey, M. (2019). Knowledge-intensive entrepreneurship and S3: Conceptualizing strategies for sustainability. Sustainability, 11(18), 4824. DOI: $10.3390 /$ su11184824.

[25] Gobattoni, F., Pelorosso, R., Leone, A. \& Ripa, M. N. (2015). Sustainable rural development: The role of traditional activities in Central Italy. Land Use Policy, 48, 412-427. DOI: 10.1016/j.landusepol.2015.06.013.

[26] Grinberga-Zalite, G., Oganisjana, K. \& Surikova, S. (2015). The Study of Social Innovation Theoretical Framework for Enhancing of Rural Development and Agriculture in Latvia. In Marketing and Sustainable Consumption. New Dimensions in the Development of Society (pp. 205-215). Jelgava: Latvia University of Agriculture.

[27] Haxeltine, A., Avelino, F., Pel, B., Dumitru, A., Kemp, R., Longhurst, N., Chilvers, J. \& Wittmayer, J. M. (2016). A framework for transformative social innovation [TRANSIT working paper, 5]. DOI: 10.13140/RG.2.2.30337.86880.

[28] Hennebry, B. \& Stryjakiewicz, T. (2020). Classification of Structurally Weak Rural Regions: Application of a Rural Development Index for Austria and Portugal. Quaestiones Geographicae, 39(2), 5-14. DOI: 10.2478/quageo-2020-0014.

[29] Howaldt, J. \& Kopp, R. (2012). Shaping social innovation by social research. In Franz. H. W., Hochgerner. J. \& Howaldt, J., eds. Challenge social innovation (pp. 43-55). Berlin, Heidelberg: Springer.

[30] Katonáné Kovács, J., Varga, E. \& Nemes, G. (2016). Understanding the process of social innovation in rural regions. Studies in Agricultural Economics, 118(1), 22-29. DOI: 10.7896/j.1604.

[31] Kluvánková, T., Brnkaláková, S., Špaček, M., Slee, B., Nijnik, M., Valero, D., Miller, D., Bryce, R., Kozová, M., Polman, N. \& Szabo, T. (2018). Understanding social innovation for the wellbeing of forest-dependent communities: A preliminary theoretical framework. Forest Policy and Economics, 97(C), 163-174. DOI: 10.1016/j.forpol.2018.09.016.

[32] Knickel, K., Redman, M., Darnhofer, I., Ashkenazy, A., Chebach, T. C., Šūmane, S., Tisenkopfs, T., Zemeckis, R., Atkociuniene, V., Rivera, M. \& Strauss, A. (2018). Between aspirations and reality: Making farming, food systems and rural areas more resilient, sustainable and equitable. Journal of Rural Studies, 59, 197-210. DOI: 10.1016/j.jrurstud.2017.04.012.

[33] Kowalski, A. A. \& Jenkins, L. D. (2015). The role of bridging organizations in environmental management: examining social networks in working groups. Ecology and Society, 20(2), 16. DOI: 10.5751/ES-07541-200216.

[34] Labianca, M., Rubertis, D. \& Salento, A. (2018). Neo-endogenous development and social innovation in rural marginal areas. The cases of Castel del Giudice (Italy) and Altiplanicies of Granada (Spain). In Cejudo García, E., Nvarro Valverde, F. A. \& Camacho Ballesta, J. A., eds., New rural realities in times of crisis: territories, actors, processes and policies (pp. 628640). Universidad de Granada. 
[35] Lombardi, M., Lopolito, A., Andriano, A. M., Prosperi, M., Stasi, A. \& lannuzzi, E. (2020). Network impact of social innovation initiatives in marginalised rural communities. Social Networks, 63, 11-20. DOI: 10.1016/j.socnet.2020.04.001.

[36] Maye, D. (2018) Examining innovation from the bottom-up: An analysis of the permaculture community in England. Sociologia Ruralis, 58, 331-350. DOI: 10.1111/soru.12141.

[37] Melnykovych, M., Nijnik, M., Soloviy, I., Nijnik, A., Sarkki, S. \& Bihun, Y. (2018). Socialecological innovation in remote mountain areas: Adaptive responses of forest-dependent communities to the challenges of a changing world. Science of the Total Environment, 613, 894-906. DOI: 10.1016/j.scitotenv.2017.07.065.

[38] Mieg, H. A. \& Töpfer, K. eds. (2013). Institutional and social innovation for sustainable urban development. London: Routledge.

[39] Miquel, M. P., Cabeza, M. G. \& Anglada, S. E. (2013). Theorizing multi-level governance in social innovation dynamics. In Moulaert, F. ed., The International Handbook on Social Innovation: Collective Action, Social Learning and Transdisciplinary Research (pp. 155-168). Cheltenham: Edward Elgar Publishing Limited.

[40] Moulaert, F., Martinelli, F., González, S. \& Swyngedouw, E. (2007). Introduction: social innovation and governance in European cities: urban development between path dependency and radical innovation. European Urban and Regional Studies 14(3), 195-209. DOI: $10.1177 / 0969776407077737$.

[41] Moulaert, F., Martinelli, F., Swyngedouw, E. \& Gonzalez, S. (2005). Towards alternative model(s) of local innovation. Urban Studies, 42(11), 1969-1990. DOI: $10.1080 / 00420980500279893$.

[42] Moulaert, F. (2009). Social innovation: Institutionally embedded, territorially (re) produced. In MacCallum, D., Moulaert, F., Hillier, J. \& Haddock, S., eds. Social innovation and territorial development (pp. 11-24). Farnham: Ashgate.

[43] Moulaert, F. ed. (2013). The international handbook on social innovation: collective action, social learning and transdisciplinary research. Cheltenham: Edward Elgar Publishing.

[44] Navarro, F., Labianca, M., Cejudo, E., de Rubertis, S., Salento, A., Maroto, J. C. \& Belliggiano, A. (2018). Interpretations of innovation in rural development. The cases of leader projects in Lecce (Italy) and Granada (Spain) in 2007-2013 period. European Countryside, 10(1), 107-126. DOI: 10.2478/euco-2018-0007.

[45] Neumeier, S. (2012). Why do social innovations in rural development matter and should they be considered more seriously in rural development research? - Proposal for a stronger focus on social innovations in rural development research. Sociologia ruralis, 52(1), 48-69. DOI: 10.1111/j.1467-9523.2011.00553.x.

[46] Neumeier, S. (2017). Social innovation in rural development: identifying the key factors of success. The Geographical Journal, 183(1), 34-46. DOI: 10.1111/geoj.12180.

[47] Nicholls, A., Simon, J. \& Gabriel, M. (2015). Introduction: Dimensions of social innovation. In Nicholls, A., Simon, J., Gabriel, M. \& Whelan, C., eds. New frontiers in social innovation research (pp. 1-26). London: Palgrave Macmillan.

[48] Nijnik, M., Secco, L., Miller, D. \& Melnykovych, M., 2019. Can social innovation make a difference to forest-dependent communities?. Forest Policy and Economics, 100, 207-213. DOI: 10.1016/j.forpol.2019.01.001.

[49] Novikova, M., de Fátima Ferreiro, M. \& Stryjakiewicz, T. (2020). Local Development Initiatives as Promoters of Social Innovation: Evidence from Two European Rural Regions. Quaestiones Geographicae, 39(2), 43-53. DOI: 10.2478/quageo-2020-0012.

[50] Noy, C. (2008). Sampling knowledge: The hermeneutics of snowball sampling in qualitative research. International Journal of Social Research Methodology, 11(4), 327-344. DOI: $10.1080 / 13645570701401305$. 
[51] Oliveira, H. \& Penha-Lopes, G. (2020). Permaculture in Portugal: Social-Ecological Inventory of a Re-Ruralizing Grassroots Movement. European Countryside, 12(1), 30-52. DOI: 10.2478/euco-2020-0002.

[52] Olsson, P., Folke, C. \& Hahn, T. (2004). Social-ecological transformation for ecosystem management: the development of adaptive co-management of a wetland landscape in southern Sweden. Ecology and Society, 9(4), 2.

[53] Ostrom, E. (2009). Understanding institutional diversity. Princeton University Press.

[54] Parés, M., Ospina, S. M. \& Subirats, J., eds. (2017). Social innovation and democratic leadership: communities and social change from below. Cheltenham: Edward Elgar Publishing.

[55] Pato, L. (2020). Entrepreneurship and Innovation Towards Rural Development Evidence from a Peripheral Area in Portugal. European Countryside, 12(2), 209-220. DOI: 10.2478/euco-2020-0012.

[56] Pinto-Correia, T., Barroso, F. \& Menezes, H. (2010). The changing role of farming in a peripheric South European area - the challenge of the landscape amenities demand. In Wiggering, H., Ende, H. P., Knierim, A. \& Pintar, M. eds., Innovations in European rural landscapes (pp. 53-76). Berlin: Springer.

[57] Richter, R. (2019). Rural social enterprises as embedded intermediaries: The innovative power of connecting rural communities with supra-regional networks. Journal of Rural Studies, 70, 179-187. DOI: 10.1016/j.jrurstud.2017.12.005.

[58] Rotmans, J. \& Loorbach, D. (2010). Towards a better understanding of transitions and their governance. A systemic and reflexive approach. In Grin, J., Rotmans, J., Schot, J. W., Geels, F. W. \& Loorbach, D., eds., Transitions to sustainable development : new directions in the study of long term transformative change (pp. 105-198). New York: Routledge.

[59] Schuitmaker, T. J. (2012). Identifying and unravelling persistent problems. Technological Forecasting and Social Change, 79(6), 1021-1031. DOI: 10.1016/j.techfore.2011.11.008.

[60] Sept, A. (2020). Thinking Together Digitalization and Social Innovation in Rural Areas: An Exploration of Rural Digitalization Projects in Germany. European Countryside, 12(2), 193-208. DOI: 10.2478/euco-2020-0011.

[61] Vanclay, F., Baines, J. T. \& Taylor, C. N. (2013). Principles for ethical research involving humans: ethical professional practice in impact assessment Part I. Impact Assessment and Project Appraisal, 31(4), 243-253. DOI: 10.1080/14615517.2013.850307.

[62] Vercher, N., Barlagne, C., Hewitt, R., Nijnik, M. \& Esparcia, J. (2020). Whose Narrative is it Anyway? Narratives of Social Innovation in Rural Areas-A Comparative Analysis of Community-Led Initiatives in Scotland and Spain. Sociologia Ruralis. DOI: $10.1111 /$ soru.12321.

[63] Westley, F. R., McGowan, K. A., Antadze, N., Blacklock, J. \& Tjornbo, O. (2016). How game changers catalyzed, disrupted, and incentivized social innovation: three historical cases of nature conservation, assimilation, and women's rights. Ecology and Society, 21(4), 13. DOI: 10.5751/ES-08811-210413.

[64] Živojinović, I., Ludvig, A. \& Hogl, K. (2019). Social innovation to sustain rural communities: Overcoming institutional challenges in Serbia. Sustainability, 11(24), 7248. DOI: $10.3390 /$ su11247248.

\section{Other sources}

[65] Avelino, F., Wittmayer, J., Haxeltine, A., Kemp, R., O'Riordan, T., Weaver, P., Loorbach, D. \& Rotmans, J. (2014). Game-changers and transformative social innovation. The case of the economic crisis and the new economy. TRANSIT working paper, 1, 4-24. Online at: 
http://www.transitsocialinnovation.eu/content/original/TRANSIT\%20outputs/91\%20Gamech angers_TSI_Avelino_etal_TRANSIT_workingpaper_2014.pdf (accessed on 12 August 2020).

[66] Eurostat (2016). Rural development statistics by urban-rural typology. Online at: https://ec.europa.eu/eurostat/statistics-

explained/index.php?title=Archive:Rural_development_statistics_by_urban-

rural_typology\&oldid=294503 (accessed on 15 November 2019).

[67] Eurostat (2019). Database. Online at: ec.europa.eu/eurostat/data/database (accessed on 25 October 2019).

[68] Godin, B (2012). "Social Innovation: Utopias of Innovation from C. 1830 to the Present." Project on the Intellectual History of Innovation, 11, 1-52. Online at: http://www.csiic.ca (assessed on 18 November 2020).

[69] Novy, A. (2017). Transformative social innovation. SRE-discussion. Multilevel Governance and Development. Online at: http://epub.wu.ac.at/5619/ (accessed on 25 July 2020).

[70] Rayner, S. (2006). Wicked Problems: Clumsy Solutions - Diagnoses and Prescriptions for Environmental Ills, Jack Beale Memorial Lecture on Global Environment. Online at: http://www.sbs.ox.ac.uk/research/Documents/Steve\%20Rayner/Steve\%20Rayner,\%20Jac k\%20Beale\%20Lecture\%20Wicked\%20Problems.pdf (accessed on 14 June 2020). 